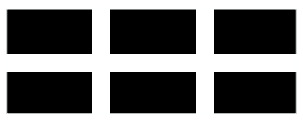

The WiLliam DAVIDSON Institute AT THE UNIVERSITY OF MICHIGAN BUSINESS SCHOOL

\title{
Technological Progress Through Trade Liberalization in Transition Countries
}

\author{
By: Yener Kandogan
}

William Davidson Working Paper Number 567

May 2003 


\author{
Yener Kandogan \\ School of Management, University of Michigan-Flint \\ 303 E. Kearsley, Flint MI 48430, USA \\ Phone: (810) 2376675 \\ E-mail: yener@umflint.edu
}

\title{
Acknowledgements
}

I specifically thank Alan Deardorff, Thomas Gresik, Jeffrey Bergstrand, Jan Svejnar, Mika Saito and Katherine Terrell for their comments and suggestions on earlier versions of this article. I also benefited from the comments of the seminar participants at the University of Notre Dame, Johns Hopkins University-SAIS Bologna, Italy, and Southern Illinois University. 


\title{
Technological Progress Through Trade Liberalization in Transition Countries
}

\begin{abstract}
Trade liberalization increases competitive pressures on domestic firms, and thus creates incentives for reducing costs of production through technological progress. Through this channel, backward countries get a chance to narrow their technological gap with more advanced countries. In this paper, the case of transition countries is analyzed. A simple model of oligopolistic firms' strategic decision on R\&D is developed to motivate the empirical analysis. The results suggest that some initial conditions such as size of the initial technological gap, and initial openness to international trade, as well as the stage of the market reforms, in particular, rate of liberalization and structure of domestic markets are important factors in narrowing the technology gap.
\end{abstract}

JEL Classification: F14, O33

Keywords: Technology gap; Trade Liberalization; Transition; Market reforms 


\section{Introduction}

East European economic performance during socialism has been characterized by technological backwardness, when compared with the industrialized economies of Western Europe. As van Brabant (1988) and Bogomolov (1987) point out, East European manufactured goods lacked sufficient quality and technical sophistication to be marketable in western markets. In particular, Monkiewicz (1989) and Winiecki (1988) provide evidence for declining prices and quality of East European engineering products, reflecting their technological backwardness. Lastly, Poznanski (1988) uses the unit values of East European exports as proxy for the level of technology, providing further evidence of this situation in the $1980 \mathrm{~s}$. Clearly, the pre-transition literature provides evidence for a wide technology gap between the West and East European economies.

Gerschenkron (1992) and Veblen (1998) state that a relatively backward country can gain from the acquisition and adaptation of the superior technology from more advanced countries. However, specific features or institutional characteristics of an economic system may preclude it from enjoying this technology flow. This was exactly the situation in during socialism. Centralized decision making, high importance given to the military industry, chronic disruptions due to administrative barriers, and lack of vertical communication can be counted as factors that restricted flow of technology. More importantly, there were specific policies designed to limit contacts with the West, as well as Western policies that restricted technology flow to the East.

With the fall of socialism, these institutional characteristics of East European economies have allegedly disappeared, so have the restrictive policies on both sides. 
These countries started a transition process towards establishing functioning market economies through reforms that included liberalization of domestic and international markets. Liberalization is expected to facilitate the learning process and thus increase the flow of technology between advanced and backward countries. Surveying developing countries undergoing liberalization, Bhagwati (1988) claims that there is little empirical evidence for technology flow. In conjunction, the theoretical work of Rodrik (1988) finds an ambiguous relationship between trade regime and flow of technology.

Considering the lack of conclusive evidence on technology flow, I analyze the situation for transition countries in a different framework. I see trade liberalization as a way of increasing competitive pressures on firms in backward countries, thus creating incentives for reducing production costs through their own technological progress rather than a flow of technology from advanced countries. In this paper, the positive impact of technological progress on international cost competitiveness mentioned in Helpman and Grossman (1990) is suggested as another driving force for progress transition countries.

Within this framework, I first compare the pre- and post-liberalization trends in the technological progress rates of transition countries to see if liberalization appears to have affected them. Rate of change in unit price of exports in technology sectors is used to proxy technological progress. I find supporting evidence for almost all liberalizing countries, although there are some differences in their technology responses. A similar exercise done for the EU countries provides evidence for a narrowing gap between transition countries and the EU.

To explain the cross-country differences, I develop a model of oligopolistic firms' strategic decisions on the rate of technological progress. In the model, firms in both 
advanced and backward countries choose their best response in terms of technological progress rate, by maximizing their intertemporal profits. The intersection of the best responses yields the equilibrium rates of progress for firms in both countries. Liberalization is modeled by a gradual reduction in tariffs over a practically infinite period of time. Technological progress is embodied in new capital with increasing returns, which lowers the marginal cost of production, but increases the fixed costs.

The primary result of the model is that trade liberalization helps backward countries close the technology gap with advanced countries through the channel of increased competition resulting from cheaper imports. However, some factors related to the stage of market reforms, such as relative structure of the domestic markets and rate of liberalization, as well as factors related to initial conditions, e.g. initial tariff rates and initial technology gap, cause the cross-country differences. Several regression exercises give empirical support for the model's findings.

\section{Trends in technological progress in transition countries}

There are 26 formerly socialist countries undergoing transition in Eurasia. ${ }^{1}$ Ten Central and East European countries (CEEC) signed the Europe Agreements (EA) with the EU countries to liberalize their trade. ${ }^{2}$ Other transition countries liberalized regionally as well. Notably, the Russian Fed., Kazakhstan, and Belarus formed the Commonwealth

\footnotetext{
${ }^{1}$ These are Albania, Armenia, Azerbaijan, Belarus, Bosnia Herzegovina, Bulgaria, Croatia, the Czech Rep., Estonia, Georgia, Hungary, Kazakhstan, Kyrgyzstan, Latvia, Lithuania, Macedonia, Moldova, Poland, Romania, The Russian Fed., the Slovak Rep., Slovenia, Tajikistan, Turkmenistan, Ukraine, and Uzbekistan.

2 The Europe Agreements came into force in 1994 with Poland, and Hungary, in 1995 with Bulgaria, Czech Republic, Romania and Slovakia, in 1998 with Estonia, Latvia and Lithuania, and in 1999 with Slovenia.
} 
of Independent States (CIS) customs union in 1994. Kyrgyzstan and Tajikistan joined it later in 1997 and 1999 respectively. Almost all transition countries have also unilaterally removed quantitative restrictions before the arrangements mentioned above. ${ }^{3}$ Some other transition countries failed to take part in these efforts for a long time due to wars and domestic civil unrests -e.g. Albania, Croatia, Bosnia Herzegovina, Macedonia, and Uzbekistan. $^{4}$ A number of regional bilateral free trade agreements were also signed by Armenia, Azerbaijan, Georgia, Kyrgyzstan, Ukraine and Moldova in late 1990s. ${ }^{5}$ Six of these countries had to be taken out of analysis because of missing data. ${ }^{6}$ The remaining countries are analyzed in three groups: CEEC with Europe Agreements with the EU, other transition countries that liberalized regionally, and those that did not.

Since the quality of manufactured goods is particularly sensitive to technology, changes in technology can be measured by changes in quality using the unit value of exports. This is the approach in the empirical analysis in this section as is in some of the pre-transition analyses. To minimize some of the well-known disadvantages of using unit values, a few steps are taken. First, changes in unit values are corrected for changes in

${ }^{3}$ EBRD gives the years for substantial removal of quantitative restrictions on imports as follows: 1989 for Hungary, 1990 for Poland, 1991 for Bulgaria, Croatia, the Czech Rep., and the Slovak Rep., 1992 for Albania, Estonia, Latvia, Lithuania, Macedonia, Romania, and the Russian Fed., 1993 for Georgia, and Slovenia, 1994 for Moldova, and Ukraine, 1995 for Azerbaijan, Belarus, and Kazakhstan.

${ }^{4}$ Macedonia singed agreements with EFTA in 2001, with Turkey and Bulgaria in 2000, with Slovenia in 1996. Croatia liberalized its trade with Slovenia in 1998.

${ }^{5}$ Armenia has agreements with Georgia in 1998, Kyrgyzstan in 1995. Azerbaijan liberalized its trade with Georgia in 1996. Similarly, Georgia has agreements with the Russian Fed. in 1994, Ukraine in 1996, Kazakhstan in 1999 and Turkmenistan in 2000. Kyrgyzstan freed its trade with the Russian Fed. in 1993, Moldova 1996, Ukraine and Uzbekistan in 1998. Ukraine also has an agreement with Estonia in 1996. Moldova also has an agreement with Romania in 1995.

${ }^{6}$ Bosnia-Herzegovina, Kyrgyzstan, and Turkmenistan, are left out of analysis because of missing labor cost data. Armenia, Tajikistan, and Uzbekistan are taken out due to non-availability of tariff data. 
labor costs. This is important because in early years of transition, these countries experienced serious decreases in real wages, with subsequent improvements. Next, the industries analyzed are limited to technology-intensive ones to increase the effect of technology on the unit values, and also to reduce the effects of other factors. Analyzing only the technology sector to represent the manufacturing sector also reduces levels of aggregation needed, and some complications associated with it. The analysis is thus confined to 11 technology-intensive industries. ${ }^{7}$ The selection process used in choosing these industries takes into account the issues raised by Globerman (1990). ${ }^{8}$ The selected industries are also consistent with those used in Pavitt (1988), and Daniels (1999).

Four-digit Harmonized System data obtained from the OECD International Trade by Commodities Statistics 1988-1996 are used to compute the unit values in US\$. Exports to the largest three developed countries, US, Japan and Germany, are used in the computations. The data set has been filtered to eliminate problematic situations: The products for which the reported unit of quantity measure changed during the period of analysis, or when the unit values for a product move wildly from one year to the next,

\footnotetext{
7 Inorganic Chemicals, Compounds of Precious Metals, Isotopes (28); Pharmaceuticals (30); Manufactured Fertilizers (31); Tanning or Dyeing Extracts; Dyes, Pigments; Paints and Varnishes; Putty and Inks (32); Polymerization Products (39); Nuclear Reactors, Boilers, Machinery and Mechanical Appliances, Computers (84); Electrical Machinery, Equipment and Parts, Telecommunications Equipment, Sound Recorders, Television Recorders (85); Vehicles other than Railway or Tramway Rolling Stock (87); Aircraft, Spacecraft and Parts (88); Optical, Photographic, Cinematographic, Measuring, Checking, Precision, Medical or Surgical Instruments and Accessories (90); Clocks and Watches, and Parts (91).

${ }^{8}$ These industries are characterized by relatively high R\&D expenditure ratios relative to value added in both the US and other OECD countries. They are also consistent with popular conceptions of
} 
implying an error in either the value or the quantity reported. Data needed to adjust for labor cost changes is obtained from different sources. ${ }^{9}$

Fig. 1(a) gives the overall trend in technological progress in CEEC before and after liberalization. Each CEEC started liberalizing its trade at different times. Therefore, the $\mathrm{x}$-axis shows the years before and after liberalization, where time 0 is the year preceding the year each country started lowering its tariff rates. ${ }^{10}$ Levels of technology are also normalized so that the index is 100 at time 0 for every country. The dark lines show the overall trend in CEEC before and after the liberalization. These are computed by simple regressions of level of technology against time. Accordingly, the level of technology in CEEC increased at a yearly average of 5.6\% before liberalization, and at $17.3 \%$ once the liberalization started. ${ }^{11}$ Fig. 1(b) gives the same plot for some EU countries. Accordingly, for the EU the average yearly increase was 5.5\% before the EA, and $7.4 \%$ after. Note that, the effect of liberalization with backward countries is a lot smaller, if significant, in more advanced countries. Furthermore, comparing the two figures, it is seen that the EAs significantly increased CEEC's chance of eventually closing the technology gap.

\footnotetext{
${ }^{9}$ European Bank for Reconstruction and Development (EBRD), Statistics Office for the Commonwealth of Independent States (CIS-Stats), and the International Financial Statistics of the IMF.

${ }^{10}$ To speed the liberalization, Interim Agreements on Trade were signed with CEEC, which became effective earlier than the EAs. Liberalization, measured as reductions in tariff revenues as percentage of imports, started in 1993 for the Czech Republic, and Bulgaria, in 1994 for Estonia, Poland, Latvia, Lithuania, Slovenia and the Slovak Republic, and in 1995 for Hungary and Romania. These years are the first year with lower tariffs for each CEEC, so they are used as time 1.

11 The overall rate of $5.5 \%$ before liberalization is obtained by taking Romania out of sample. With Romania, the overall rate appears to be $-1.2 \%$. In both cases, liberalization affects the trend positively.
} 
Fig. 2(a) gives the trend for the CIS countries that are liberalizing. ${ }^{12}$ The positive impact of liberalization on technology is observed in the CIS as well. In particular, the average rate of increase in level of technology is $19.3 \%$ in pre-liberalization period and $34.4 \%$ once the liberalization started. Fig. 2(b) gives the decreasing trend for the other transition countries that did not liberalize during the period analyzed. ${ }^{13}$ For these countries, the level of technology in 1996 is normalized to 100. Accordingly, these countries were unable to reverse the declining trend without liberalizing their trade.

Individual average yearly progress rates before and after liberalization, $\beta_{\text {before }}$, and $\beta_{\text {affer, }}$ and the change in this trend in levels, $\Delta \beta$, are given in Table 1 for all transition countries. Most countries started liberalizing when the decreasing trend in unit values established by pre-transition literature was over. Romania, Latvia and the Russian Fed. were the only countries that were still under the influence of that trend. After liberalization, all countries except Belarus, Lithuania and Poland experienced an increase in the rate of technological progress, some large, some small. The decrease in trend for Poland is seemingly insignificant. Almost all non-liberalizing transition countries were still experiencing declining unit values. Moldova and Ukraine are two exceptions, which experienced small increases.

Note that in terms of initial conditions and approach in liberalization, transition countries are very diverse. Some of these differences are given in Table 1. One obvious

\footnotetext{
${ }^{12}$ During the period analyzed, Azerbaijan, and the Russian Fed. experienced a decrease in their average tariffs rates in 1995, and Belarus and Kazakhstan in 1994. The time 0 in plots is the year preceding the above years, where the unit value of their technology exports is normalized to 100 .

${ }^{13}$ Albania, Croatia, Georgia, Macedonia, Moldova, and Ukraine.
} 
difference is their partner in liberalization. Other important factors are the initial conditions these countries started the liberalization with: The size of domestic market, measured by GDP, in Russia is about 80 times larger than that in Estonia. The initial technology gap, measured by the reciprocal of per capita gross domestic product, $G D P / L$, is 18 times smaller for Slovenia than that for Belarus. The initial tariff rates measured by import duties as percentage of value of imports, $\tau_{0}$, vary from 0.9 in Estonia to 35.4 in Azerbaijan. Apart from the initial conditions, the countries also differ in the degree of reforms achieved. Some are known to be fast reformers, like Hungary and Poland, which liberalized their domestic and international markets rapidly. Some, however, are yet to realize important market reforms, e.g. Romania, and the Slovak Republic. This can be observed by the amount of tariff reductions carried out during the period analyzed, $r$, in Table 1. Lastly, the amount of FDI received by these countries is vastly different. Cumulative net FDI inflows during the period of analysis is less than 500 million US\$ for seven countries, whereas it amounts to impressive numbers such as 13 billion for Hungary, 7 billion for the Czech Rep., and over 5 billion for the Russian Fed., and Poland. ${ }^{14}$

In sum, the trade liberalization in the CEEC, and the CIS regional appear to have a positive effect on their progress rates. The magnitude of these effects, however, has been different for each country. All the differences mentioned above likely play a role in countries' technology responses to liberalization.

\footnotetext{
${ }^{14}$ Since FDI leads to a flow of technology from advanced countries rather than a self-induced technological progress, it will be used as a control variable as it partly explains the cross-country differences observed.
} 


\section{The model}

The model in this section tries to explain the cross-country differences observed in technology response to liberalization. There are two countries and one industry with differentiated products: $n^{A}$ varieties are produced in country $A$, and $n^{B}$ varieties in country $B$. Representative consumers in each country consume these varieties according to a CES utility function. For example in country $A$, the consumers maximize:

$$
U_{t}^{A}=\left(\sum_{i=1}^{n^{A}}\left(C_{i t}^{A(A)}\right)^{1 / 2}+\sum_{i=1}^{n^{B}}\left(C_{i t}^{A(B)}\right)^{1 / 2}\right)^{2}
$$

subject to the following budget constraint:

$$
\sum_{i=1}^{n^{A}} P_{i t}^{A} C_{i t}^{A(A)}+\sum_{i=1}^{n^{B}} P_{i t}^{A(B)} C_{i t}^{A(B)}=Y_{t}^{A}
$$

where $C_{i t}^{A(A)}$ is the consumption of a domestic variety in $A$ at time $t, C_{i t}^{A(B)}$ is the consumption in country $A$ of a variety produced in $B . Y_{t}^{A}$ is the income in country $A$. $P_{i t}^{A}$ and $P_{i t}^{A(B)}$ are the prices of domestic and imported varieties consumed in country $A$. In particular, because of the symmetry of the problem: ${ }^{15}$

$$
\begin{aligned}
& P_{i t}^{A}=P_{t}^{A} \\
& P_{i t}^{A(B)}=P_{i t}^{B}\left(1+\tau_{t}^{A}\right)=P_{t}^{A(B)}=P_{t}^{B}\left(1+\tau_{t}^{A}\right)
\end{aligned}
$$

where $\tau_{t}^{A}$ is the tariff rate that country $A$ applies to its imports at time $t$. Transportation costs are ignored. Both countries liberalize their trade. In particular, for country $A$ :

\footnotetext{
${ }^{15}$ Each variety is produced by a different firm, and firms in each country have the same technology. Therefore, each firm's profit maximization problem is similar.
} 


$$
\tau_{t}^{A}=\tau_{o}^{A} e^{-r^{A} t}
$$

where $r^{A}$ is the rate of liberalization in country $A . \tau_{o}^{A}$ is the initial tariff level that $A$ levies on its imports from $B$.

$C_{i t}^{A(A)}$ and $C_{i t}^{A(B)}$ are found by solving the representative consumer's utility maximization problem:

$$
\begin{aligned}
& C_{i t}^{A(A)}=C_{t}^{A} \forall i \text { in } n^{A} \\
& C_{t}^{A}=\frac{Y_{t}^{A}}{P_{t}^{A}} \frac{1}{n^{A}+n^{B}\left(\frac{P_{t}^{B}}{P_{t}^{A(B)}}\right)} \\
& C_{i t}^{A(B)}=C_{t}^{A(B)} \forall i \text { in } n^{B} \\
& C_{t}^{A(B)}=\frac{Y_{t}^{A}}{P_{t}^{B}} \frac{1}{n^{A}\left(\frac{P_{t}^{A(B)}}{P_{t}^{A}}\right)+n^{B}}
\end{aligned}
$$

Firms in each country operate in oligopolistic industries. All $n^{A}$ firms in country $A$ have the same technology, each producing a different variety. Similarly, $n^{B}$ firms in country $B$ have identical technology within $B$ but different from that in $A$. This is reflected to their total cost functions as follows:

$$
T C_{t}^{A}=F C_{t}^{A}\left(\beta^{A}\right)+M C_{t}^{A}\left(\beta^{A}\right) Q
$$

where the fixed and the constant marginal costs of production are functions of $\beta^{4}$, rate of technological progress in $A$.

Technological improvements are embodied in new capital equipment, and are subject to increasing returns. That is, by incurring greater levels of fixed costs of capital, firms can obtain higher levels of labor productivity through innovations. Consequently, the fixed and the marginal costs change over time as follows: 


$$
\begin{aligned}
& F C_{t}^{A}\left(\beta^{A}\right)=F C_{o}^{A} e^{\beta^{A} t} \\
& M C_{t}^{A}\left(\beta^{A}\right)=M C_{o}^{A} e^{-\beta^{A} t}
\end{aligned}
$$

As technology progresses, fixed costs increase due to higher initial cost of high tech capital. Marginal cost, on the other hand, decreases due to increases in productivity of labor resulting from technological progress. This formulation allows firms to choose from a menu of technologies as suggested in Gans (1998). Assuming that country $A$ is initially more advanced:

$$
F C_{o}^{A}>F C_{o}^{B} \text { and } M C_{o}^{A}<M C_{o}^{B}
$$

Firms in each country choose a rate of technological progress to maximize their profits intertemporally in two stages: Firms first choose the rate of technological progress, and then, as tariffs go down and technology improves, they choose the profitmaximizing prices for their outputs given the current level of technology, the tariff rates and the prices of the varieties produced in the other country.

The model is solved using backward induction: Given a rate of progress, the profit-maximizing price in $\mathrm{A}$ is:

$$
P_{t}^{A}=\frac{M C_{t}^{A}}{1+\frac{1}{\varepsilon_{t}^{A}}} \quad \varepsilon_{t}^{A}=\gamma_{t}^{A(A)} \varepsilon_{t}^{A(A)}+\gamma_{t}^{B(A)} \varepsilon_{t}^{B(A)}
$$

where $\varepsilon_{t}^{A}$ is the overall elasticity of demand for a variety produced in $A$, comprised of $\varepsilon_{t}^{A(A)}$ and $\varepsilon_{t}^{B(A)}$, which are the domestic and foreign demand elasticities for a variety produced in $A$, respectively. $\gamma_{t}^{A(A)}$ and $\gamma_{t}^{B(A)}$ are the shares of domestic market and the export market, respectively, for a country- $A$ variety: 


$$
\gamma_{t}^{A(A)}=\frac{C_{t}^{A}}{Q_{t}^{A}}, \gamma_{t}^{B(A)}=\frac{C_{t}^{B(A)}}{Q_{t}^{A}} \text { where } \gamma_{t}^{A(A)}+\gamma_{t}^{B(A)}=1
$$

After some calculations, the overall elasticity is obtained:

$$
\begin{aligned}
& \varepsilon_{t}^{A}=-\gamma_{t}^{A(A)}\left(1+\frac{1}{\left(\frac{n^{A}}{n^{B}}\right)\left(\frac{P_{t}^{B}}{P_{t}^{A}}\right)\left(1+\tau_{t}^{A}\right)+1}\right)-\gamma_{t}^{B(A)}\left(1+\frac{1}{\left(\frac{n^{A}}{n^{B}}\right)\left(\frac{P_{t}^{B}}{P_{t}^{A}}\right)\left(\frac{1}{1+\tau_{t}^{B}}\right)+1}\right) \\
& \varepsilon_{t}^{A}=-1-z_{t}^{A}\left(\frac{n^{A}}{n^{B}}, \tau_{t}^{A}, \tau_{t}^{B}, \frac{P_{t}^{A}}{P_{t}^{B}}\right)
\end{aligned}
$$

where $1 / z_{t}^{A}$ is the profit rate at the margin in country $A$ :

$$
P_{t}^{A}=M C_{t}^{A}\left(1+\frac{1}{z_{t}^{A}}\right)
$$

Using a similar equation for $B$, one can solve for the equilibrium price ratio:

$$
\frac{P_{t}^{A}}{P_{t}^{B}}=\frac{P_{t}^{A}}{P_{t}^{B}}\left(\frac{M C_{t}^{A}}{M C_{t}^{B}}, \frac{n^{A}}{n^{B}}, \tau_{t}^{A}, \tau_{t}^{B}\right)
$$

Having the profit maximizing price ratio that depends on the progress rates through the marginal costs, firms then choose the progress rates that maximize the intertemporal profit:

$$
\int_{o}^{\infty} e^{-\rho^{A} t} \pi_{t}^{A} d t-\Phi\left(\beta^{A}\right)=\int_{o}^{\infty} e^{-\rho^{A} t}\left(\frac{M C_{t}^{A}}{z_{t}^{A}} Q_{t}^{A}-F C_{t}^{A}\right) d t-\Phi\left(\beta^{A}\right)
$$

where $\Phi\left(\beta^{4}\right)$ represents the discounted value of expenditures made on technological effort. These expenditures are assumed to increase with the rate of technological progress at a decreasing rate. $\rho^{A}$ is the discount rate in country $A$. Solutions to this problem in each country give the best response functions that is used to find the equilibrium progress rates: 


$$
\begin{aligned}
& \beta^{A}=\beta^{A}\left(\beta^{B}, \frac{\tau_{o}^{A}}{\tau_{o}^{B}}, \frac{r^{A}}{r^{B}}, \frac{M C_{o}^{A}}{M C_{o}^{B}}, \frac{n^{A}}{n^{B}}, \rho^{A}\right) \\
& \beta^{B}=\beta^{B}\left(\beta^{A}, \frac{t_{o}^{A}}{t_{o}^{B}}, \frac{r^{A}}{r^{B}}, \frac{M C_{o}^{A}}{M C_{o}^{B}}, \frac{n^{A}}{n^{B}}, \rho^{B}\right)
\end{aligned}
$$

\section{The model's results}

In this section, I analyze the effects of factors in the best response functions on the equilibrium progress rates to find out the factors that are conducive to narrowing the technological gap.

Despite the fact that the model was constructed as the minimum needed to address the issues mentioned, an analytical solution was not practical. Therefore, the results in this section come from simulations based on the model. The results presented assume certain benchmark values for the variables of the model. ${ }^{16}$ These values are later varied to analyze the effects of each variable on the rate of technological progress. Robustness analysis shows that the validity of the results can be maintained.

Fig. 3 (a) - (d) give the results of these simulations. Each panel shows the effect of only one parameter on the equilibrium progress rates. In each simulation, it is assumed that all other characteristics of the two countries are identical. For example in panel (a), the following is assumed to observe only the effect of the initial gap size:

\footnotetext{
$16 \tau_{o}^{A}$ and $\tau_{o}^{B}:[\mathbf{5 0 \%}, 100 \%, 200 \%], r^{A}$ and $r^{B}:[0.05,0.2, \mathbf{0 . 1}], M C_{o}^{A}$ and $M C_{o}^{B}:[\mathbf{0 . 0 0 5}, 0.025,0.05]$; $F C_{o}^{A}$ and $F C_{o}^{A}:[0.25,0.5, \mathbf{1}, 2] ; n^{A}$, and $n^{B}:[10, \mathbf{1 0 0}, 400,1000] ; \rho^{A}$ and $\rho^{B}:[0.1,0.2, \mathbf{0 . 3}]$
} 


$$
\frac{n^{A}}{n^{B}}=1 \quad \frac{\tau_{o}^{A}}{\tau_{o}^{B}}=1 \quad \frac{r^{A}}{r^{B}}=1
$$

Fig. 3(a) gives the effect of this initial gap, measured by $\frac{M C_{o}^{A}}{M C_{o}^{B}}$, on the rate of technological progress. Different gaps considered are 1, 0.5, 0.25, and 0.1, which imply that the advanced country is initially as productive, twice, four times, and ten times as productive as the backward country, respectively. First observe that, all equilibrium points are to the left of the $45^{\circ}$ line, implying a narrowing of the technology gap. The backward country strategically adopts a higher rate of technological progress than the more advanced country. Furthermore, one can see that the larger the gap is (the smaller $\left.\frac{M C_{o}^{A}}{M C_{o}^{B}}\right)$ the faster the gap narrows with liberalization.

Having established that trade liberalization leads to a narrowing of the technology gap, let us now turn to determining what factors amplify or dampen this by relaxing the equalities assumed in (16). For simulation results given in (b)-(d), I assume that there is no technological gap between the two countries, and relax only one of the identities in equation (16) in each exercise.

Fig. 3(b) gives the effect of the relative market structure, $\frac{n^{A}}{n^{B}}$, measured by the relative numbers of varieties (firms). The ratios assumed are 1/3,1/2, 1, 2, and 3, which cover both smaller and larger ratios for country $A$ relative to country $B$. Accordingly, with liberalization, the country with a smaller number of varieties strategically adopts a higher

The numbers in bold are assumed in the reported results. The function assumed for R\&D expenditures, $\Phi(\beta)$, is $\sqrt{ } \beta$. Although the model is for oligopolistic firms, the results here are not sensitive to number of 
progress rate. If one country produces more varieties than the other, the firms in latter country have to compete with many firms. This is the reason why they have to adopt a higher progress rate, even if there is no initial technology gap. This factor helps the catching up process of transition countries. Their economies were associated with highly concentrated industries that did not produce many varieties.

The effect of initial openness, measured by $\frac{\tau_{o}^{A}}{\tau_{o}^{B}}$, is given in Fig. 3(c). The ratios considered are $0.5,1$, and 2 , which imply that country $A$ 's initial tariff rates are half of, the same as, or twice as high as country $B$ 's initial tariff rates, respectively. The figure shows that with liberalization, the initially more closed country strategically adopts a higher progress rate than the more open country. The more open country is already subject to fierce international competition, and thus a high rate of technological progress is already in place. Further liberalization for that country has only minor effects. The more closed country, however, starts facing international competition with trade liberalization. Therefore, it needs to adopt a higher rate of technological progress to stay competitive. Transition economies during socialism were almost autarkic. However, during the turbulent early stages of transition some countries unilaterally lowered their trade barriers significantly to discipline their domestic markets and to realign their domestic relative prices with the world prices. Analysis here shows that these unilateral liberalizations have worked to dampen narrowing of the technology gap due to the bilateral liberalizations, such as the Europe Agreements.

firms. 
Finally, Fig. 3(d) gives the effect of the relative liberalization rate, $\frac{r^{A}}{r^{B}}$, on technological progress. The ratios analyzed are $0.5,1$, and 2 , which imply that country $A$ reduces its tariff rates half as fast as, as fast as, or twice as fast as country $B$, respectively. Accordingly, the faster liberalizing country strategically adopts a higher rate of innovation than the slower one. Firms in the faster liberalizing country feel competitive pressures sooner, thus they have to adopt a higher rate of technological progress to stay competitive. The Europe Agreements adopted an unbalanced liberalization policy. About $70 \%$ of EU imports were freed upon signature, whereas only $10-20 \%$ of CEEC imports were freed at the same time. This unbalanced pattern was preserved in removal of further tariff barriers. Liberalization was faster on the EU side, and according to the model, this feature of the EAs slows down the CEEC in advancing their level of technology towards that of the EU.

\section{Regression results}

First, a few regressions are carried out including all countries, whether liberalized or not, to establish that liberalization makes a difference in the progress of technology. The results are given in Table 2. Then, liberalizing countries' technology responses are regressed against the factors described in the previous section. Tables 3 and 4 give the regression results for CEEC, and for CEEC and liberalizing CIS combined, respectively.

In these regressions, the reciprocal of $G D P$ per capita is used to proxy for the initial technology, $M C_{0}$. Low $G D P / \mathrm{L}$ implies low productivity, and backward technology. According to the model, low $G D P / L$ speeds up the technological progress. $G D P$ is used to represent the number of varieties produced in a country, $n$. The model 
shows that a lower GDP in the backward country implies faster narrowing of the gap among countries with the same trade partner. The initial tariff rates, $\tau_{0}$, are the tariff rates in the year before the liberalization starts. According to the model, higher initial tariff rates in backward countries imply faster narrowing of the technology gap. Lastly, the average yearly rates of liberalization, $r$, are calculated using the tariff rates in the year of liberalization and in the latest year available. The model implies that a higher rate of liberalization in the backward country implies faster narrowing of the gap.

In the Table 2 regressions, technological trend in all transition countries are first regressed against simply a constant, and a dummy for liberalizing countries, $D_{l i b}$. Later, other variables are added: $F D I / G D P$ to control for the flow of technology through FDI; $G D P / L$ to take into account the differences in technology gaps across the transition countries; and lastly, a dummy for liberalizing CIS countries, $D_{c i s}$, to see how the results of their liberalization differ from that of CEEC. The sign of $D_{l i b}$ is positive as expected and statistically significant. The signs of $F D I / G D P$ and $G D P / L$ are also as expected but not significant. $D_{c i s}$ is positive and significant, which implies that liberalization had a greater positive impact on CIS than on CEEC.

The degrees of freedom for the regressions in Table 3 are very low due to the very small sample size - just ten CEEC countries. Despite this inconvenience, three out of four regressors have the expected sign according to the model with the exception of $r$, the rate of liberalization. To capture the country dynamics affecting the technological progress rate, other than liberalization, $\beta_{\text {before }}$, the rate before the EA liberalization is added to the regressors in (2). This addition to the regression model did not change the signs of the coefficients. Excluding the country with the most negative technological response to 
liberalization, Lithuania, as an outlier did not affect the signs either. Lastly, adding the FDI/GDP to control for the flow of technology as a regressor failed to change the unexpected sign of $r$, as seen in regressions (3) and (4).

Note that the unilateral liberalizations done by the transition countries before the EA complicate the identification of the sign of the variables in the regressions, especially that of the initial tariff rate and the rate of liberalization. Significant unilateral liberalization results in low initial tariff rates for the period analyzed, as well as low rates of liberalization thereafter. According to the model, both low initial tariff rates, and low rates of liberalization implies slow technological progress. However, the country may still experience high rates of progress due to unilateral liberalization rather than due to the EA itself. This complication might explain the unexpected sign of r. Note also the interaction between $r$ and $\tau_{0}$ : If initial tariff rate is low due to a unilateral liberalization, the rate of any subsequent liberalization is bound to be lower. To deal with these issues, two more regressions are carried out. In regressions (5) and (6), either $r$ or $\tau_{0}$ is omitted, and the regression is carried out with the remaining variables. Both of these regressions give the correct signs for all coefficients according to the model's expectations.

In Table 4, the sample of liberalizing countries is expanded with the inclusion of four CIS countries. In regression (1), the signs of variables are as expected with the exception of $r$, as was the case in regressions including CEEC only. The inclusion of $\beta_{\text {before, and } F D I / G D P}$ in regression (2) results in correct signs for all variables, although mostly insignificant. Greater response to liberalization by the CIS is again observed when $D_{c i s}$ is added to regressors in regression (3). 
The difference between the liberalizations done by the CEEC and CIS cannot be explained by simply adding a dummy variable. According to the model, particular characteristics of the partner countries are important as well as those of the backward partner being analyzed. In the Table 2 regressions, this is not important as the partner for all CEEC was the same. When the sample covers both CEEC and CIS, the differences between their partners need to be taken into account. According to the model for the same backward country, the more advanced the partner is, the faster is the technological catching up since the initial technology gap is wider. Therefore for the CIS, the effect of $G D P / L$ is smaller, since their regional partners are more backward than the partner of CEEC, the EU. The model also suggests that the larger the partner's size, GDP, the faster the gap narrows. Since the EU is economically bigger than the CIS partners, the variable GDP has a smaller effect for the CIS. The initial tariff rate, and the rate of liberalization of the partners also make a difference. According to the model, initially more open, and slower liberalizing partner helps the backward partner in catching up. Since the CIS partners are initially more closed and liberalized at a much slower rate than the EU, the effect of $\tau_{0}$ is smaller, and that of $r$ is higher for the CIS. These implications of the model are incorporated to the regression by the interaction of the variables in concern with $D_{\text {cis }}$. As seen in regression (4) in Table 4, the signs of all the variables and the interactions are as expected, although insignificant. The only exception is the interaction with $G D P / L .^{17}$

\footnotetext{
${ }^{17}$ Although not of primary concern, the sign of FDI/GDP is also opposite of what is generally expected.
} 


\section{Conclusions}

Analyzing transition countries, the empirical analysis of this paper finds an overall positive effect of trade liberalization on narrowing a technology gap. Some countries experienced strong increases in their technological progress rates after liberalization. Some, however, experienced smaller effects. Those that did not liberalize failed to reverse the declining trend in their technology. The theoretical model of the paper tries to explain these cross-country differences in technology response to liberalization. Accordingly, some factors characterizing the economies of transition countries, such as an autarkic structure during socialism, unilateral liberalizations in early stages of market reforms, highly concentrated industries, and wide technology gaps with the West, as well as some characteristics of the trade liberalizations: the choice of trade partners (the EU versus the CIS), and faster liberalization on the EU side in the Europe Agreements for the CEEC are critical. Model's results imply that the autarkic structure before socialism amplified the effect of the liberalization on progress rates of the transition countries, whereas unilateral liberalizations early in 1990s dampened the effect of the subsequent bilateral liberalizations. For the CEEC, faster liberalization on the EU side also dampened the narrowing of the technology gap. The highly concentrated structure of the industries in the transition countries increased the speed of narrowing technology gap. Lastly, the choice of trade partners proved to be important. If the partner is more advanced, initially more open, and economically bigger -all leading to fiercer competition once liberalization starts- like the EU, the chances of narrowing the technology gap are higher. Despite the small size of the sample, several regression experiments give support to the model's results. 


\section{References}

Bhagwati, J., (1988). 'Export-Promoting Trade Strategy: Issues and Evidence', The World Bank Research Observer 3.

Bogomolov, O., (1987). 'The Socialist Countries at a Critical Stage in World Economic Development', Problems of Economics 30 (8), pp. 38-54.

Daniels, P., (1999). 'Economic Gains from Technology-Intensive Trade: An Empirical Assessment', Cambridge Journal of Economics 23, pp. 427-447.

Gans, J., (1998). 'Industrialization with a Menu of Technologies: Appropriate Technologies and the "Big Push", Structural Change and Economic Dynamics 9, pp. $333-48$.

Gerschenkron, A., (1992). Economic Backwardness in Historical Perspective. In: Granovetter,M. and Swedberg, R. (Eds). The Sociology of Economic Life. Westvire Press, Boulder and Oxford. Previously published: [1952]. 
Globerman, S., (1990). Canada: Technology and Competitiveness. In: Soesastro, H. and Pangestu, M. (Eds), Technological Challenge in the Asia-Pacific Economy. Allen \& Unwin, Sydney.

Grossman, G., and Helpman, E., (1990). 'Comparative Advantage and Long-run Growth', American Economic Review 80, pp. 796-815.

Monkiewicz, J., (1989). International Technology Flows and the Technology Gap: The Experience of Eastern European Socialist Countries in International Perspective. Westview Press, Boulder.

Pavitt, K., (1988). 'International Patterns of Technological Accumulation', In: Hood, N., and Vahlne, J. (Eds), Strategies in Global Competition, Croom Helm, London.

Poznanski, K. Z., (1988). 'Economic Determinants of Technological Performance in East European Industry', Eastern European Politics and Societies 2 (3), pp. 577-600.

Rodrik, D., (1988). 'Closing the Technology Gap: Does Trade Liberalization Really Help?’ NBER Working Paper \#2654.

van Brabant, J., (1988). 'Production Specialization in the CMEA: Concepts and Empirical Evidence', Journal of Common Market Studies 26(3), pp. 287-315.

Veblen, T., (1998). 'Outline of a Policy for the Control of the Economic Penetration of Backward Countries, and of Foreign Investments' In: Veblen T. (Ed), Essays in our changing order. New Brunswick, N.J. and London. Previously published: [1932].

Winiecki, J., (1988). The Distorted World of Soviet-Type Economies, University of Pittsburgh Press, Pittsburgh. 


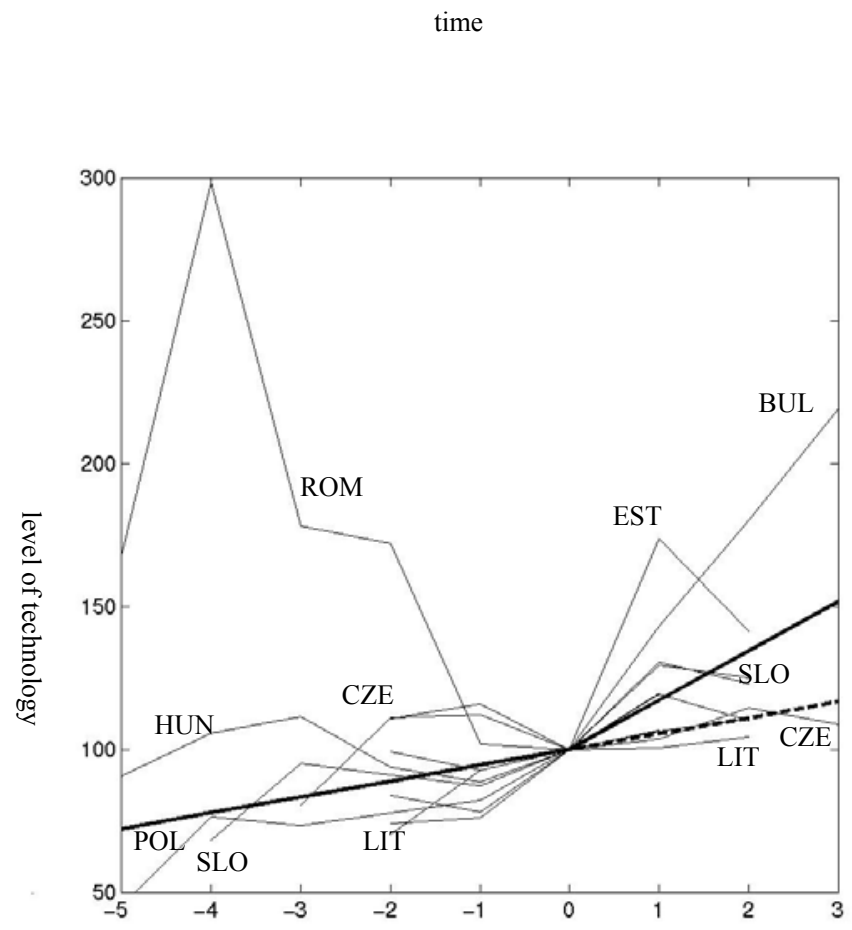

(a) CEEC countries 


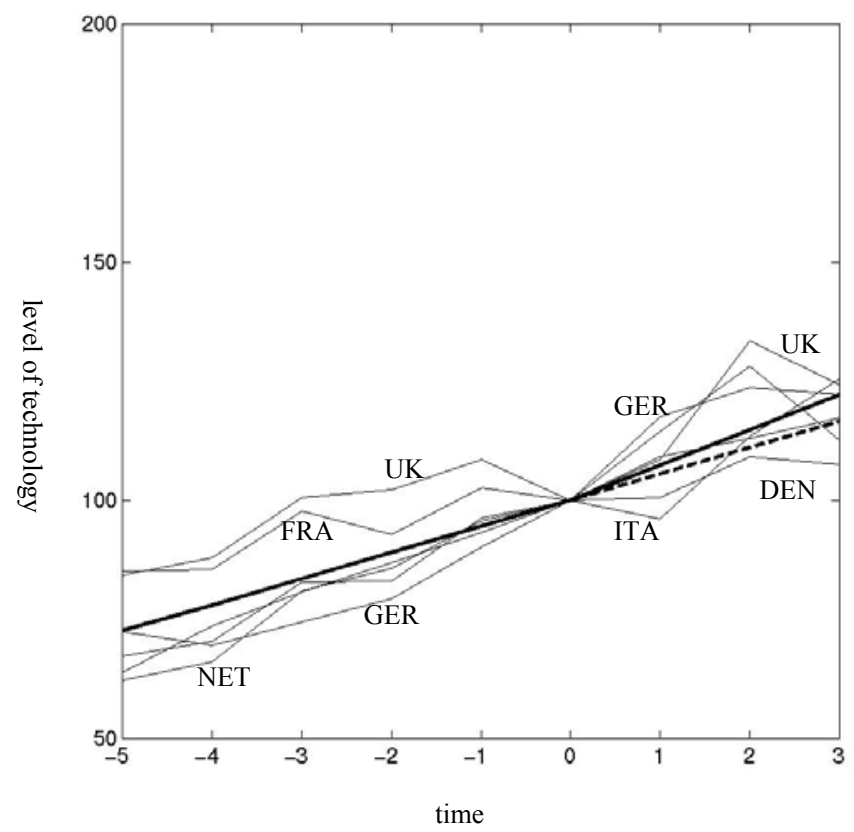

(b) The EU countries

Source: OECD, EBRD and the author's own calculations.

Fig. 1. Technological progress before and after liberalization in CEEC and the EU

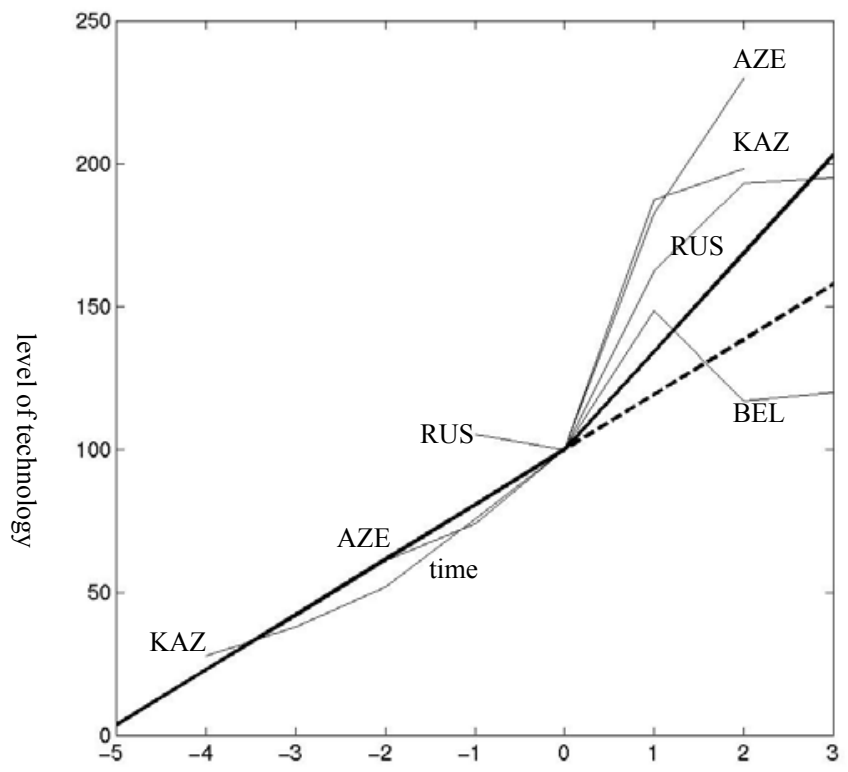

(a) Liberalizing countries 


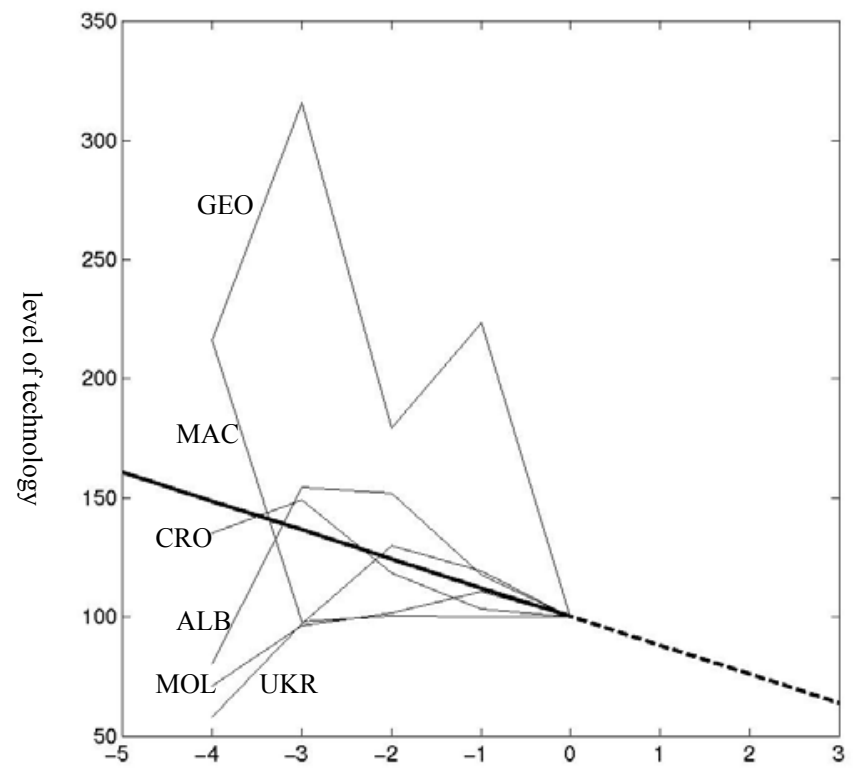

(b) Non-liberalizing countries

Source: OECD, CIS-Stats, and the author's own calculations.

Fig 2. Technological progress in liberalizing and non-liberalizing transition countries

Table 1. Differences among transition countries

\begin{tabular}{|c|c|c|c|c|c|c|c|c|c|}
\hline Country & Partner & $\beta_{\text {before }}{ }^{(a)}$ & $\beta_{\text {after }}$ & $\Delta \beta$ & $G D P^{(b)}$ & $G D P / L$ & $\tau_{0}{ }^{(c)}$ & $r^{(d)}$ & $F D I^{(e)}$ \\
\hline Bulgaria & EU & 10.78 & 40.14 & 29.36 & 10.4 & 1,012 & 7.1 & 2.5 & 425 \\
\hline Czech Rep. & EU & 1.75 & 4.23 & 2.48 & 29.8 & 2,903 & 3.5 & 0.9 & 7,120 \\
\hline Estonia & $\mathrm{EU}$ & 15.25 & 31.37 & 16.12 & 3.9 & 1,105 & 0.9 & 0.9 & 735 \\
\hline Hungary & $\mathrm{EU}$ & 0.24 & 6.71 & 6.47 & 41.5 & 4,069 & 13.0 & 3.3 & 13,260 \\
\hline Latvia & EU & -7.52 & 5.55 & $\begin{array}{l}13.07 \\
\text { time }\end{array}$ & 5.3 & 836 & 3.2 & 1.7 & 644 \\
\hline Lithuania & $\mathrm{EU}$ & 13.27 & 1.87 & -11.4 & 6.1 & 754 & 3.0 & 1.8 & 285 \\
\hline Poland & EU & 8.96 & 7.9 & -1.06 & 86.0 & 2,234 & 17.4 & 7.4 & 5,398 \\
\hline Romania & EU & -27.51 & 19.57 & 47.08 & 25.1 & 859 & 6.6 & 0.9 & 1,186 \\
\hline Slovak Rep. & EU & 5.75 & 16 & 10.25 & 12.7 & 2,258 & 3.4 & 0.5 & 623 \\
\hline Slovenia & EU & 1.76 & 15.33 & 13.57 & 12.5 & 6,261 & 7.3 & 1.2 & 743 \\
\hline
\end{tabular}




\begin{tabular}{l|crrr|rrrr|r}
\hline Azerbaijan & CIS & 20.67 & 68.62 & 47.95 & 3.3 & 246 & 35.4 & 30.2 & 987 \\
Belarus & CIS & 19.67 & 10.16 & -9.51 & 27.0 & 350 & 7.7 & 4.6 & 167 \\
Kazakhstan & CIS & -5.29 & 38.29 & 43.58 & 25.8 & 981 & 4 & 2 & 3,067 \\
Russian Fed. & CIS & 19.85 & 56.83 & 36.98 & 325.9 & 1,870 & 15 & 7.2 & 5,843 \\
Albania & - & -6.87 & - & - & 1.8 & 537 & 7.6 & - & 298 \\
Croatia & - & -10.98 & - & - & 14.6 & 3,413 & 7.8 & - & 615 \\
Georgia & - & -46.44 & - & - & 2.5 & 534 & 1 & - & 39 \\
Macedonia & - & -15.34 & - & - & 2.6 & 1,593 & 11.5 & - & 76 \\
Moldova & - & 3.72 & - & - & 4.2 & 360 & 1.2 & - & 161 \\
Ukraine & - & 3.27 & - & - & 71.4 & 541 & 1.9 & - & 1,270 \\
\hline
\end{tabular}

(a) Technology progress rates are measured as the average annual percentage change in export unit value.

(b) GDP and per capita GDP are the values in the year before liberalization started, measured in US\$. GDP is in billions of US\$.

(c) These are average tariff rates observed in the year immediately preceding the year of liberalization.

(d) These are amount of reductions in average tariff rates during the period analyzed.

(e) These are the cumulative net FDI inflows during the period analyzed in millions of US\$.

Source: Technology progress rates come from author's own calculations. Data on tariffs, GDP, and FDI are obtained from the EBRD and the World Bank.

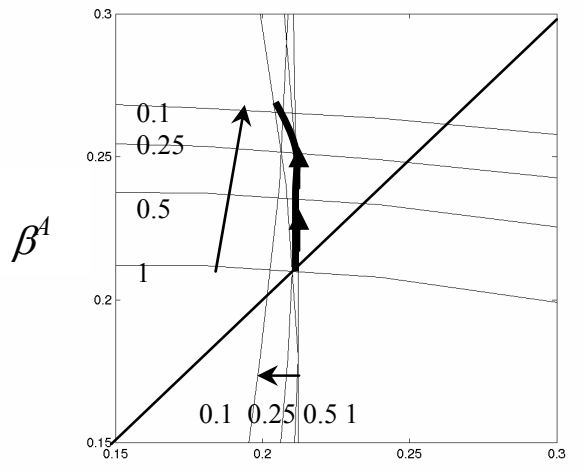

(a) Effect of $\frac{\beta^{B}}{\boldsymbol{M \boldsymbol { C } _ { \boldsymbol { o } } ^ { \boldsymbol { B } }}}$

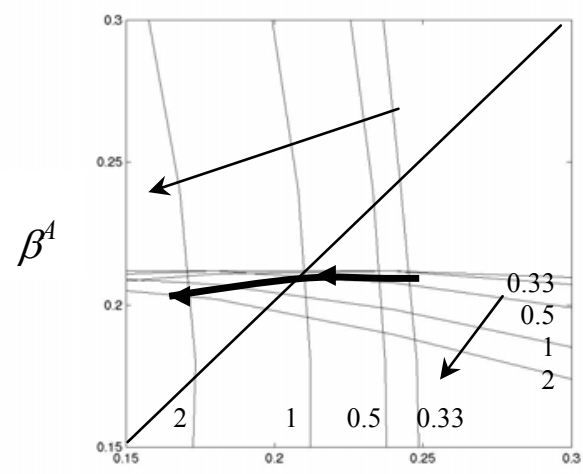

$\beta^{B}$

(b) Effect of $\frac{n^{A}}{n^{B}}$ 

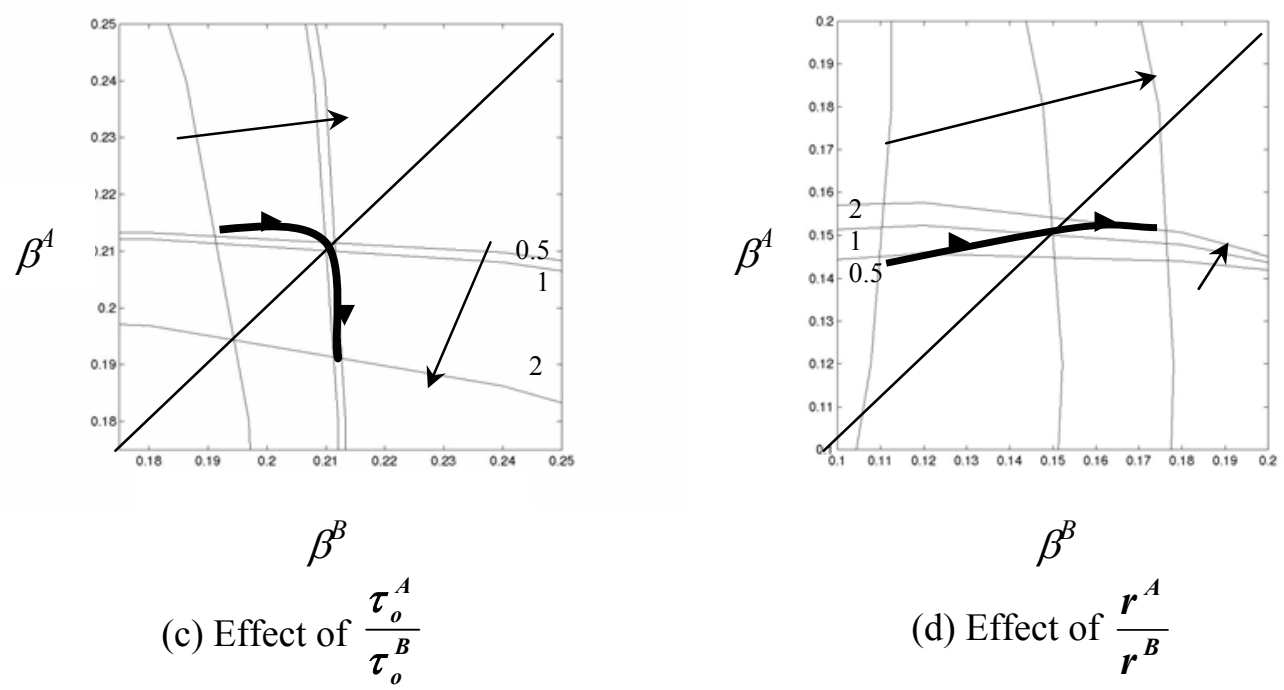

Notes: Horizontal and vertical light shaded lines are the best response functions for the backward and advanced country, respectively. Bold lines show the location of equilibrium progress rates. Arrows show the direction of best response functions, and equilibrium progress rates as
(a) technology gap widens
(b) the backward country produces relatively fewer varieties
(c) the backward country initially has lower tariff rates
(d) the backward country liberalizes relatively slower

Fig. 3. Effects of initial gap, relative size, initial openness, and rate of liberalization 


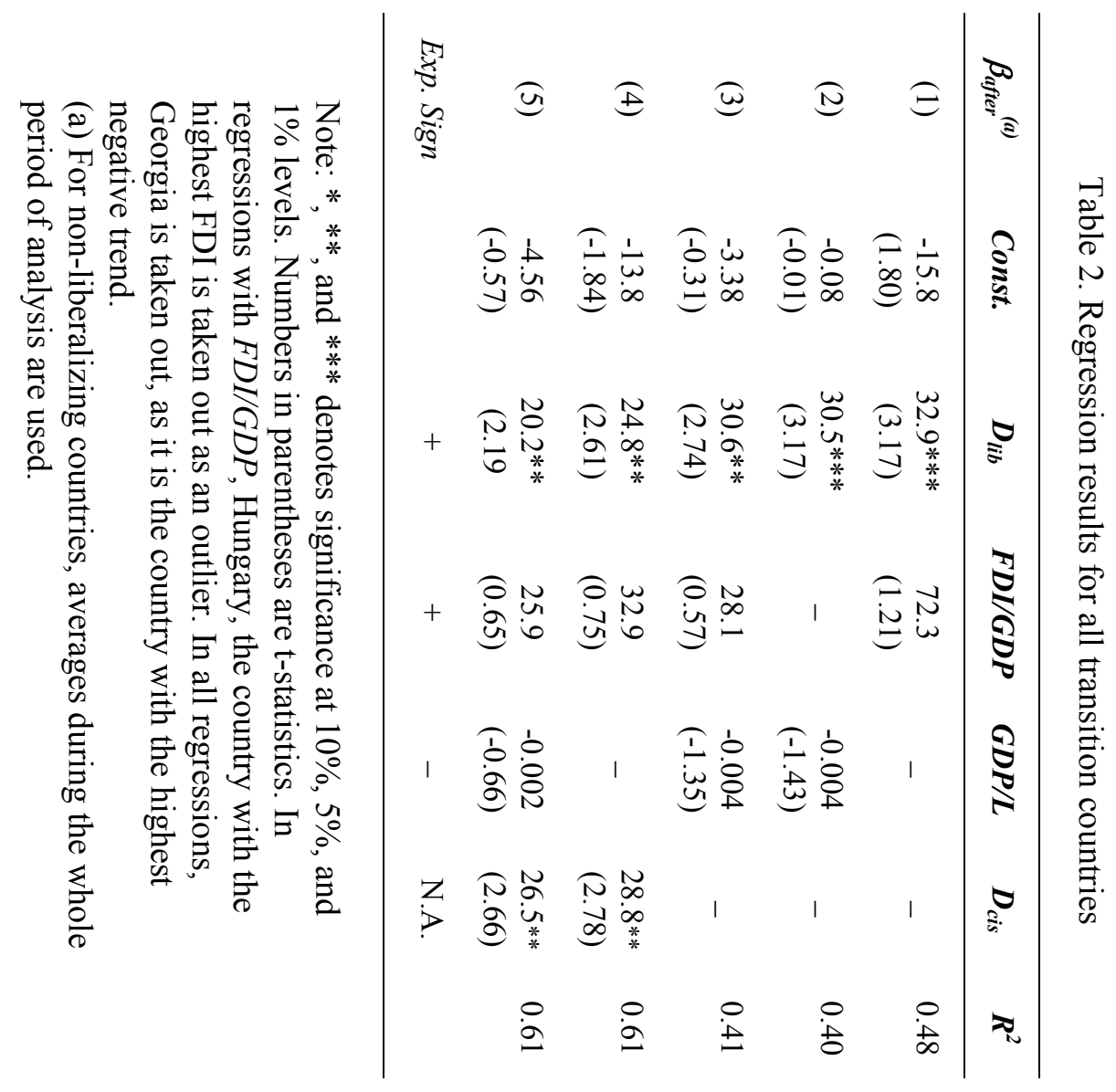




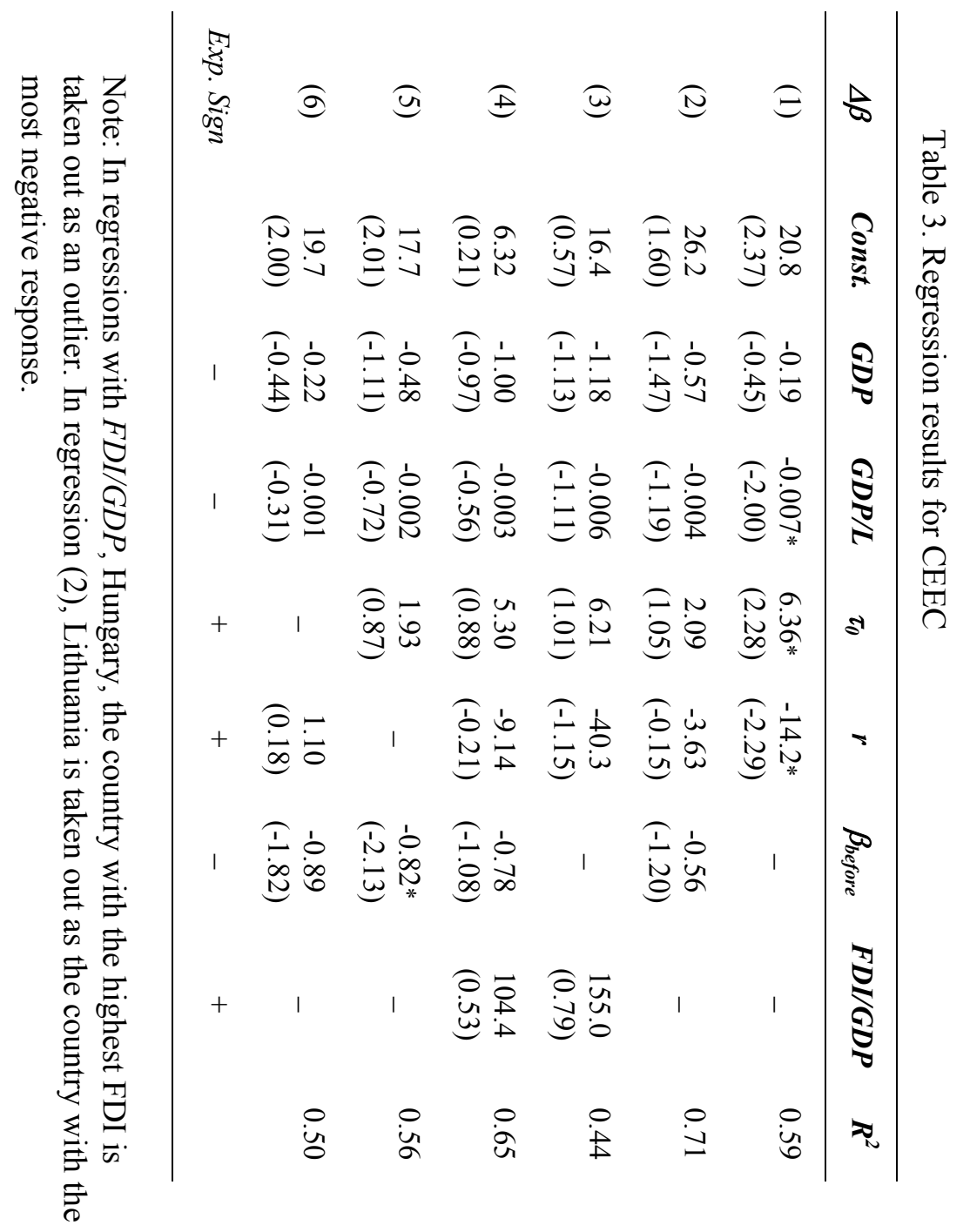




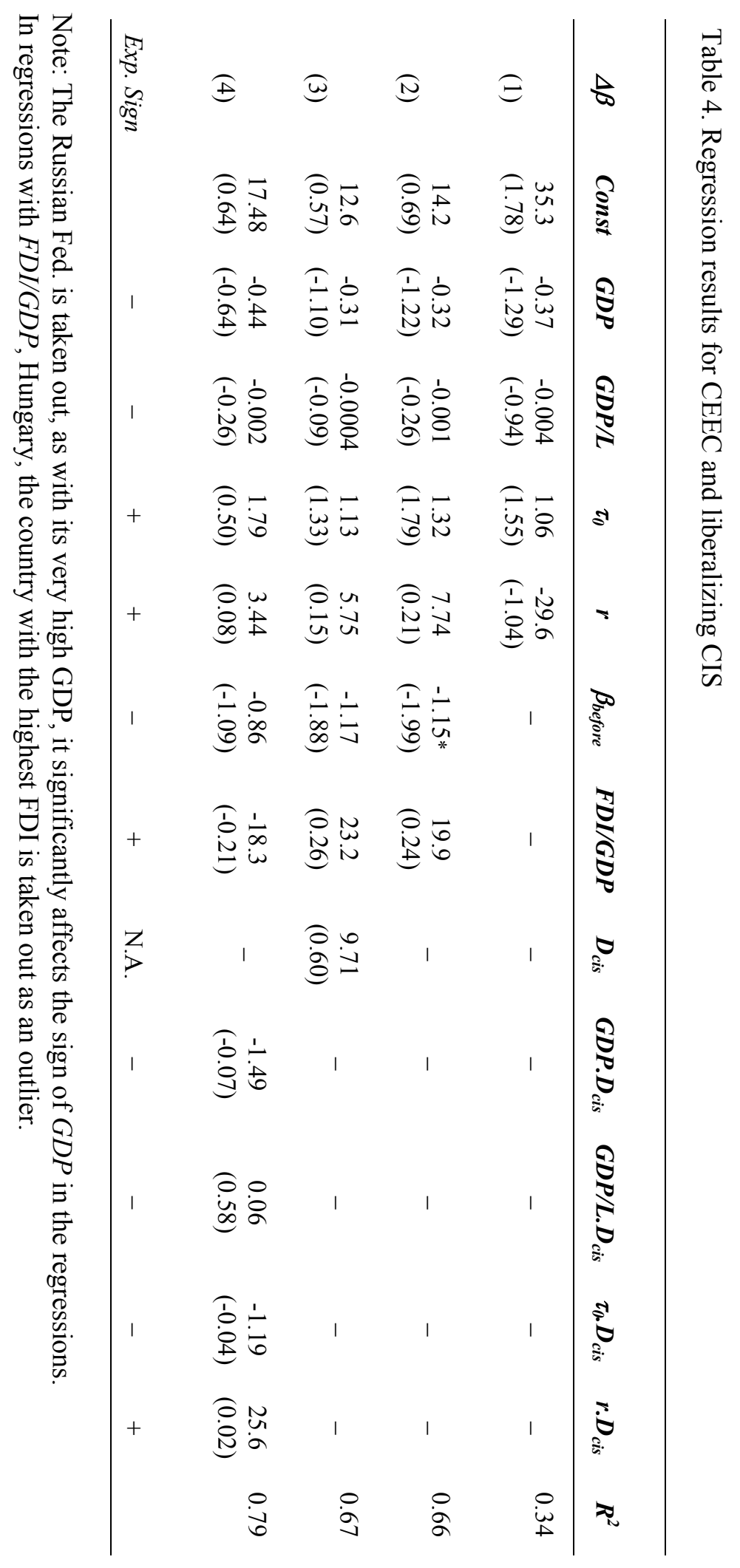




\section{DAVIDSON INSTITUTE WORKING PAPER SERIES - Most Recent Papers}

The entire Working Paper Series may be downloaded free of charge at: www.wdi.bus.umich.edu

CURRENT AS OF 5/1/03

\begin{tabular}{|c|c|c|}
\hline Publication & Authors & Date \\
\hline $\begin{array}{l}\text { No. 567: Technological Progress Through Trade Liberalization in } \\
\text { Transition Countries }\end{array}$ & Yener Kandogan & May 2003 \\
\hline $\begin{array}{l}\text { No. 566: Intra-industry Trade of Transition Countries: Trends and } \\
\text { Determinants }\end{array}$ & Yener Kandogan & May 2003 \\
\hline $\begin{array}{l}\text { No. 565: Local Protectionism and Regional Specialization: Evidence } \\
\text { from China's Industries }\end{array}$ & $\begin{array}{l}\text { Chong-En Bai, Yingjuan Du, } \\
\text { Zhigang Tao, Sarah Y. Tong }\end{array}$ & May 2003 \\
\hline No. 564: Corporate Governance and Market Valuation in China & $\begin{array}{l}\text { Chong-En Bai, Qiao Liu, Joe Lu, } \\
\text { Frank M. Song, and Junxi Zhang }\end{array}$ & May 2003 \\
\hline $\begin{array}{l}\text { No. 563: Revenue Sharing and Control Rights in Team Production: } \\
\text { Theories and Evidence From Joint Ventures }\end{array}$ & $\begin{array}{l}\text { Chong-En Bai, Zhigang Tao, and } \\
\text { Changqi Wu }\end{array}$ & May 2003 \\
\hline $\begin{array}{l}\text { No. 562: Financial Dependence, Stock Market Liberalizations and } \\
\text { Growth }\end{array}$ & Nandini Gupta and Kathy Yuan & May 2003 \\
\hline $\begin{array}{l}\text { No. 561: Growth and Regional Inequality in China During the Reform } \\
\text { Era }\end{array}$ & Derek Jones, Cheng Li and Owen & May 2003 \\
\hline $\begin{array}{l}\text { No. 560: Choice of Ownership Structure and Firm Performance: } \\
\text { Evidence from Estonia }\end{array}$ & $\begin{array}{l}\text { Derek Jones, Panu Kalmi, Niels } \\
\text { Mygind }\end{array}$ & May 2003 \\
\hline No. 559: Explaining Postcommunist Economic Performance & Lawrence P. King & May 2003 \\
\hline $\begin{array}{l}\text { No. 558: Tax Structure and the FDI: The Deterrent Effects of } \\
\text { Complexity and Uncertainty }\end{array}$ & $\begin{array}{l}\text { Kelly Edmiston, Shannon Mudd } \\
\text { and Neven Valev }\end{array}$ & Apr. 2003 \\
\hline No. 557: Provincial Protectionism & Konstantin Sonin & Apr. 2003 \\
\hline $\begin{array}{l}\text { No. 556: Nominal and Real Convergence in Estonia: The Balassa- } \\
\text { Samuelson (dis)connection }\end{array}$ & Balázs Égert & Apr. 2003 \\
\hline $\begin{array}{l}\text { No. 555: Banks-Firms Nexus under the Currency Board: Empirical } \\
\text { Evidence from Bulgaria }\end{array}$ & $\begin{array}{l}\text { Nikolay Nenovsky, Evgeni Peev } \\
\text { and Todor Yalamov }\end{array}$ & Apr. 2003 \\
\hline $\begin{array}{l}\text { No. 554: To Steal or Not to Steal: Firm Attributes, Legal Environment, } \\
\text { and Valuation }\end{array}$ & Art Durnev and E. Han Kim & Apr. 2003 \\
\hline No. 553: Corporate Stability and Economic Growth & $\begin{array}{l}\text { Kathy S. He, Randall Morck and } \\
\text { Bernard Yeung }\end{array}$ & Apr. 2003 \\
\hline $\begin{array}{l}\text { No. 552: So Many Rocket Scientists, So Few Marketing Clerks: } \\
\text { Occupational Mobility in Times of Rapid Technological Change }\end{array}$ & $\begin{array}{l}\text { Nauro F. Campos and Aurelijus } \\
\text { Dabušinskas }\end{array}$ & Mar. 2003 \\
\hline $\begin{array}{l}\text { No. 551: Determinants of Interregional Mobility in Russia: Evidence } \\
\text { from Panel Data }\end{array}$ & $\begin{array}{l}\text { Yuri Andrienko and Sergei } \\
\text { Guriev }\end{array}$ & Feb. 2003 \\
\hline $\begin{array}{l}\text { No. 550: Gross Job Flows in Ukraine: Size, Ownership and Trade } \\
\text { Effects }\end{array}$ & $\begin{array}{l}\text { Jozef Konings, Olga Kupets and } \\
\text { Hartmut Lehmann }\end{array}$ & Mar. 2003 \\
\hline $\begin{array}{l}\text { No. 549: Technology Transfer through FDI in Top-10 Transition } \\
\text { Countries: How Important are Direct Effects, Horizontal and Vertical } \\
\text { Spillovers? }\end{array}$ & $\begin{array}{l}\text { Jože P. Damijan, Mark Knell, } \\
\text { Boris Majcen and Matija Rojec }\end{array}$ & Feb. 2003 \\
\hline $\begin{array}{l}\text { No. 548: Does Foreign Direct Investment Increase the Productivity of } \\
\text { Domestic Firms? In Search of Spillovers through Backward Linkages }\end{array}$ & Beata K. Smarzynska & Mar. 2003 \\
\hline $\begin{array}{l}\text { No. 547: Re-employment Probabilities and Wage Offer Function for } \\
\text { Russian Labor Market }\end{array}$ & Natalia V. Smirnova & Feb. 2003 \\
\hline $\begin{array}{l}\text { No. 546: Democratization's Risk Premium: Partisan and Opportunistic } \\
\text { Political Business Cycle Effects on Sovereign Ratings in Developing } \\
\text { Countries }\end{array}$ & $\begin{array}{l}\text { Steven Block, Burkhard N. } \\
\text { Schrage and Paul M. Vaaler }\end{array}$ & Feb. 2003 \\
\hline $\begin{array}{l}\text { No. 545: Structural Reforms and Competitiveness: Will Europe } \\
\text { Overtake America? }\end{array}$ & Jan Svejnar & Feb. 2003 \\
\hline No. 544: Why the Rich May Favor Poor Protection of Property Rights & Konstantin Sonin & Dec. 2002 \\
\hline $\begin{array}{l}\text { No. 543: Reinvested Earnings Bias, The "Five Percent" Rule and the } \\
\text { Interpretation of the Balance of Payments - With an Application to } \\
\text { Transition Economies }\end{array}$ & $\begin{array}{l}\text { Josef C. Brada and Vladimír } \\
\text { Tomšík }\end{array}$ & Feb. 2003 \\
\hline $\begin{array}{l}\text { No. 542: The Impact of Ownership Reform in Chinese Industry, 1995- } \\
2001\end{array}$ & $\begin{array}{l}\text { Gary H. Jefferson, Su Jian, Jiang } \\
\text { Yuan and Yu Xinhua }\end{array}$ & Feb. 2003 \\
\hline
\end{tabular}

